\title{
Factors affecting market outlet choice of wheat producers in North Gondar Zone, Ethiopia
}

\author{
Abebe Birara Dessie*, Tadie Mirie Abate and Taye Melese Mekie
}

\begin{abstract}
Background: Selecting the appropriate channels to deliver farm products is not an easy task because there are various factors that affect producers to select such relevant channels. Hence, the study was aimed to investigate the factors that influence market channel choices among wheat producers in Northwestern Ethiopia.

Methods: Using multistage sampling technique, 163 smallholder wheat producers were selected to collect primary data through semi-structures questionnaires. Combinations of data analysis methods such as descriptive statistics and econometrics model (multivariate probit model) were used.

Result and conclusion: The study identified four major wheat market channel choices such as retailers, assemblers, consumers and wholesalers as alternatives to wheat producers to sell majority of their products. Thus, retailers who accounted for $40.49 \%$ of total sold, assemblers (39.2\%), consumers (37.5\%) and wholesalers (23.93\%). The results of a multivariate probit model indicated that age of household, education status, credit access; livestock number, off-farm income and total land-holding size of farmers significantly affected the market channel choice decisions in one or another way. Therefore, strengthening institutions to deliver timely and appropriate credit service and training to a farmer is among the major recommendations from this study.
\end{abstract}

Keywords: Outlet choice, Wheat, Multivariate probit model, Ethiopia

\section{Background}

Commercializing smallholder farmers in the agricultural sector is an indispensable path to boost economic growth and development of most developing countries, including Ethiopia [6]. In the country, cereal production and marketing are the main means of livelihood for millions of smallholder households. In Ethiopia, wheat is the main cereal crop produced for consumption and marketing purpose and ranking fourth next to maize, sorghum and teff by constitute $13.25 \%$ (1.63 million ha) from total cereal production [9].

According to [12], Ethiopia is the second largest wheat producer country in Africa, next to Egypt on 2015/2016 production season (Fig. 1). This implies there

*Correspondence: a.birara@yahoo.com

Department of Agricultural Economics, College of Agriculture and Rural

Transformation, University of Gondar, P.O. BOX 196, Gondar, Ethiopia is a potential of wheat production though producers and traders, and consumers faced many problems on wheat marketing system.

Likewise, wheat is the most vital crop in Ethiopia, ranking fourth in total cereals production (16\%) next to maize, sorghum and teff [9]. Moreover, wheat is grown as a staple food in the highlands of Ethiopia, at altitudes ranging from 1500 to 3000 masl. Nearly, all the wheat in country is produced under rain-fed conditions predominantly by small farmers. However, a few governments owned large-scale (state) farms and commercial farms to produce wheat. Despite the recent expansion on wheat production, Ethiopia falls short of being self-sufficient in wheat production, and is currently a net importer of wheat grain [11]. Figure 2 summarizes wheat land harvested and production in the Ethiopia from year 20102016 [12]. 

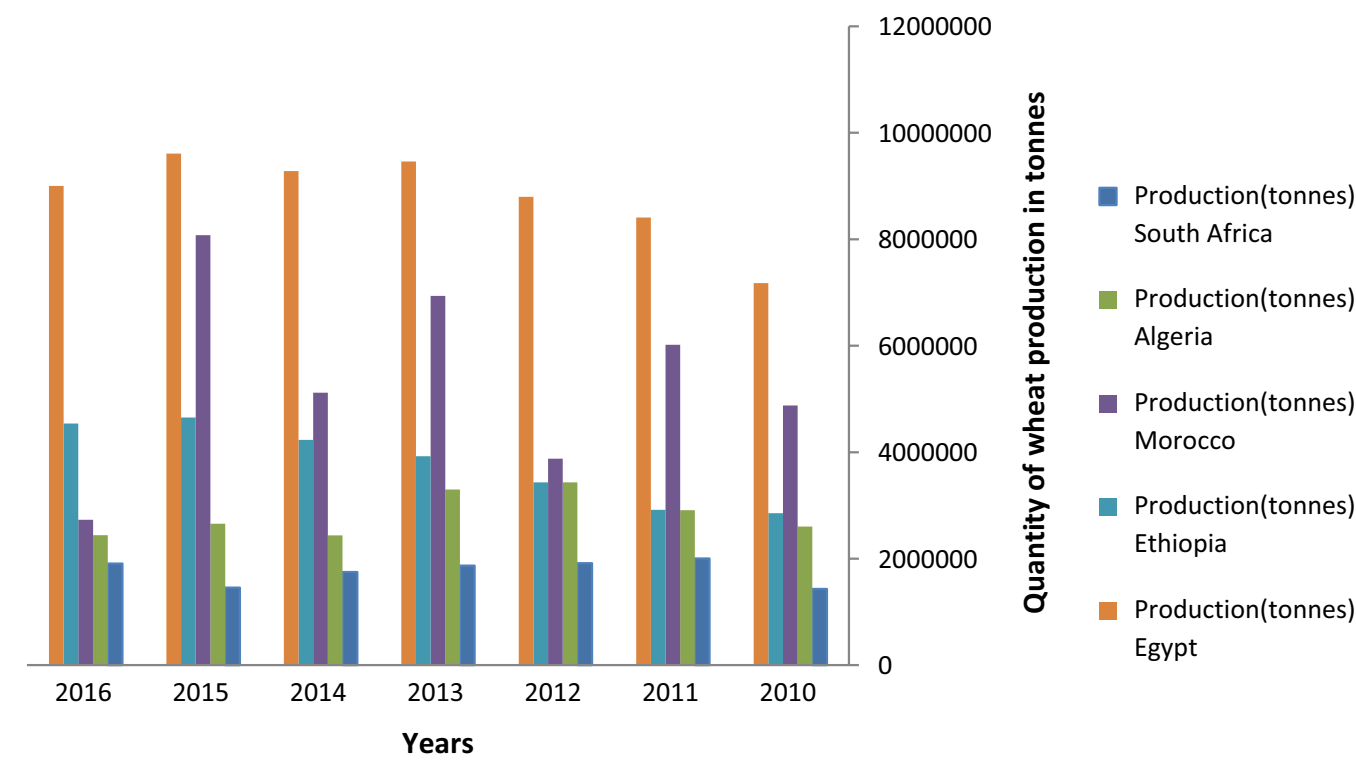

Fig. 1 Top five wheat producer countries in Africa

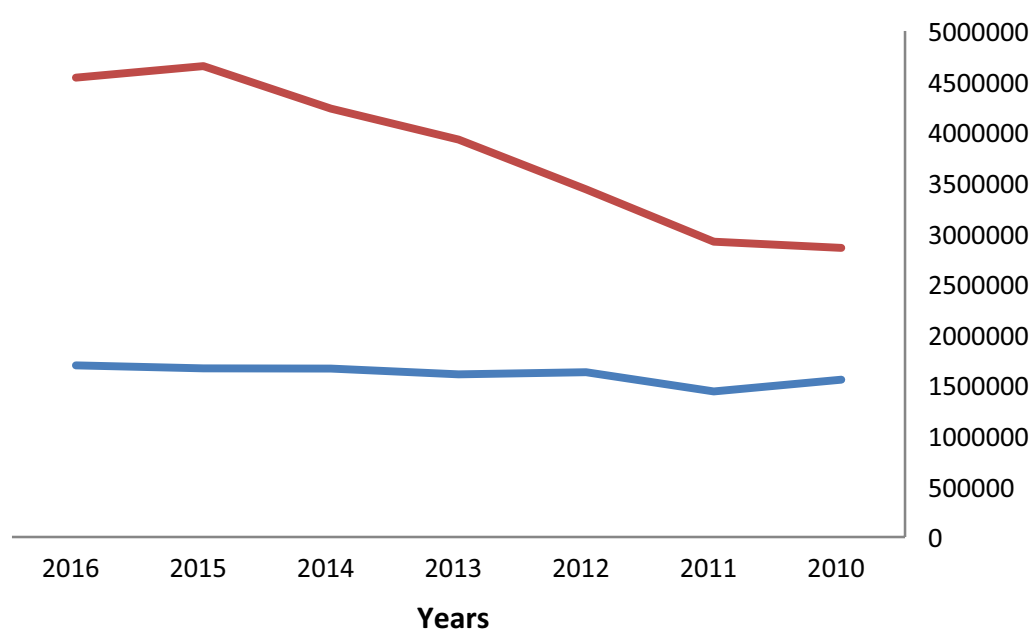

Fig. 2 Wheat production in Ethiopia

The largest volume of wheat output originates from three main regions of the country which is Oromia (55\%), Amhara (29\%) and the Southern Nations, Nationalities, and Peoples Region, SNNPR (9\%) [8].

Market is an institution which provides various welfare gains to many actors such as producers, trader and consumers from trade through specialization according to the principles of comparative advantage [3]. Market participation decision provided as a solution to boost the welfare of households in most developing countries and move them out from the poverty line [22]. Likewise, [13] revealed that to improve the livelihood of most households, it was imperative to develop their market participation, chain competitiveness and efficiency. Though there is a high potential of wheat production, producers faced many constraints to participate in market and select appropriate market outlet. The main constraint that many farmers faced is lack of market participation due to poor infrastructure [5]. Market outlet choice is an important farm household-specific decision to sell their produce in different market outlets for generating high returns [18].

Similarly, producers select their marketing plans and assess outside options that are available before 
participating in alternative wheat market channels and choose relevant market outlets based on utility maximization among existing alternatives, comparative advantage in bargaining and accessibility of channels for farm products [19]. However, smallholder farmers' decision to select appropriate market outlets can be affected by various factors such as demographic, institutional factors, socioeconomic factors and access of market outlets [4, $16,18-20]$.

In North Gondar Zone, there is an extensive cereal production, particularly wheat, sorghum, and barley. Based on the information obtained from [1], cereal marketing in the Zone is constrained by inadequate transportation network, limited numbers of traders and market outlets, inadequacy of credit access, weak bargaining power of producers, lack of flour industries, price instability, lack of storage facilities, poor-quality mechanism and weak market information. There is also different market outlets selected by producers in order to sell their agricultural products to get maximum return. However, not much has been done on what factors that affect the market outlet choice decision of smallholders in the study area. Hence, this study aimed to identify factors that influence wheat market outlet choice, in order to narrow the information gaps between producers, consumers, cooperatives, traders and other market participants. The result of this study can help to develop improved market development strategies which may play a great role for all stakeholders who want to participate in wheat market chain and value chain along the study area.

\section{Research methodology Description of study area}

The study was conducted in North Gondar Zone, Amhara National Regional State of Ethiopia. The Zone is located on the northwestern part from the country between 11 and 13 North latitude and 35 and 35 East longitudes, $738 \mathrm{~km}$ far from Addis Ababa. The zonal capital is Gondar, and geographically the city is located at $12 \mathrm{~N}$ latitude and 37E longitudes with average elevation of $2133 \mathrm{~m}$ above sea level. The boundaries of the Zone adjoin Tigray region in the North, Awi Zone and West Gojam Zone in the South, Waghimra Zone and South Gondar Zone in the East and the Sudan in the West. The Zone is dominated by the agricultural sector, which employs about $90 \%$ of the working force. The total area of the Administrative Zone is 50,970 square $\mathrm{km}$. Moreover, the Zone has a total population of 2,921,470 (84.12\% rural and $15.88 \%$ urban) of which $1,481,726$ are men and 1,439,744 are women [7]. The study was conducted in four district of the North Gondar Zone of Ethiopia, namely Gondar zuria, Wogera, Dabat and Debarik districts (Fig. 3).

\section{Sampling technique and sample size}

A multistage sampling technique was employed to select potential wheat producer respondents. In the first stage, four potential wheat producer districts, namely Gondar zuria, Wogera, Dabat and Debark districts, were purposively selected due to wheat production potentials. In the second stage, 12 potential wheat producer kebeles/ villages/from those districts were purposively selected in consultation with each district's agriculture office expert due to their best household heads production experience on wheat commodity. In the third stage, using the kebele inhabitants lists 163 wheat producers were selected using systematic random sampling techniques using the following formula [23].

$$
n=\frac{N}{1+N\left(e^{2}\right)}
$$

where $n$ is sample size to be computed, $N$ is the total size of wheat producers in the study area, and $e$ is the level of precision. The minimum level of precision is acceptable at $10 \%$. However, for this study $8 \%$ of precision level was used.

\section{Data source and method of data collection}

Combinations of quantitative and qualitative data gathered from both primary and secondary sources were used for this study. The interview schedule was administered on 163 sample household heads, which were the main source of the data-collection tool in the research work, and it was asked orally/personally/.

\section{Methods of data analysis and model specification}

Too effectively handle and analyze the diverse data collected from the field and producers, combination of different descriptive analysis methods (frequencies, percentages and means) and econometrics models such as multivariate probit model was used. The multivariate probit mode for multiple-choice problem takes the general form as follows:

The selection of wheat market channel $i$ by farmer $j$ is $Y_{i j}^{A}$ defined as the choice of farmer $j$ to transact in wheat market channel $i\left(Y_{i j}^{A}=1\right)$ or not $Y_{i j}^{A}=0$ is expressed as follows:

$$
Y_{i j}^{A}= \begin{cases}1 & \text { if } 1 \text { if } Y_{I J}^{A}=x_{i j}^{A} \alpha_{i j}+\varepsilon^{A} \geq 0 \Leftrightarrow X_{i j}^{A} \geq-\varepsilon^{A} \\ 0 & \text { if } \quad 0 \text { if } Y_{i j}^{A}=x_{i j}^{A} \alpha_{i j}+\varepsilon^{A}<0 \Leftrightarrow X_{i j}^{A}<-\varepsilon^{A}\end{cases}
$$




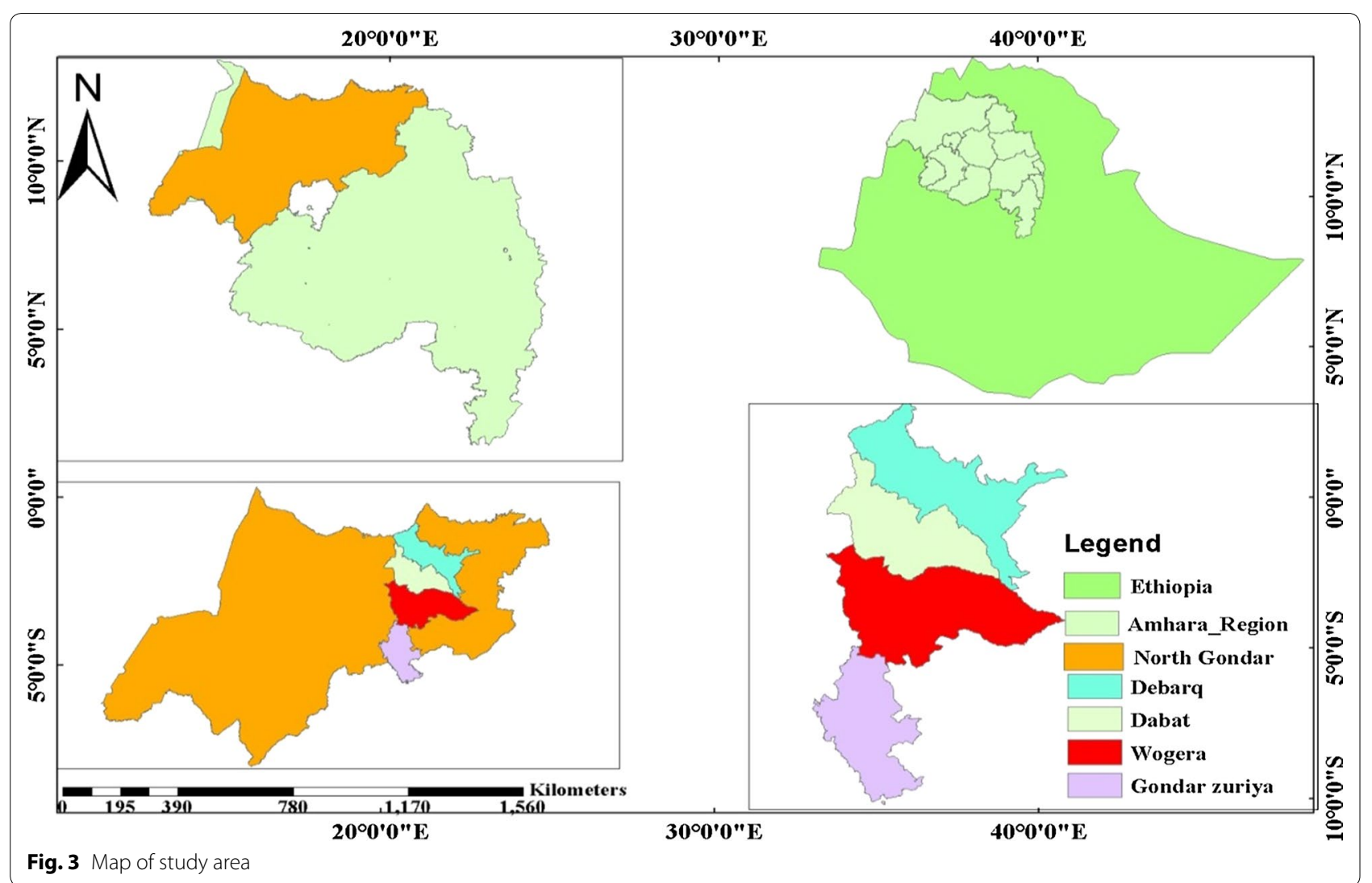

where $\alpha_{i j}^{A}$ is a vector of estimators and $\varepsilon^{A}$ is a vector of errors terms under the assumption of normal distribution, $Y_{i j}^{A}$ is dependent variable for wheat market channel choice of assembler, wholesalers, retailers and consumers and $X_{i j}^{A}$ is combined effect of the explanatory variables.

However, binary probit/Logit/and Multinomial probit/ Logit/models did not consider the possible inter-relationships between the various market channels [24]. Hence, multivariate probit model considers the interdependent and simultaneous choice decisions of various channels [2, 10]. Therefore, to analyze factors that affect outlet choice decision of smallholder farmers on wheat commodities multivariate probit mode (MVP) was used. Econometrics model specification for market channel choice is as follows:

$$
\left\{\begin{array}{l}
\text { Cons }_{j}=X_{1}^{\prime} \beta_{1}+\varepsilon^{C} \\
\text { Assem }_{j}=X_{2}^{\prime} \beta_{2}+\varepsilon^{A} \\
\operatorname{Ret}_{j}=X_{3}^{\prime} \beta_{3}+\varepsilon^{R} \\
\text { Whol }_{j}=X_{4}^{\prime} \beta_{4}+\varepsilon^{W}
\end{array}\right.
$$

where Cons $s_{j}$ Assem, Ret $t_{j}$ and $W h o l_{j}$ are binary variables taking values 1 when farmer $j$ selects consumers, assemblers, retailers and wholesalers, respectively, and 0 otherwise; $X_{1}$ to $X_{4}$ are vector of variables; $\beta_{1}$ to $\beta_{4}$ a vector of parameters to be estimated and $\varepsilon$ disturbance term. In multivariate model, the choice of several market outlets is possible, the error terms jointly follow a multivariate normal distribution (MVN) with zero conditional mean and variance normalized to unity, and the symmetric covariance matrix $\Omega$ is given by:

$$
\Omega=\left[\begin{array}{llll}
1 & \rho_{12} & \rho_{13} & \rho_{14} \\
\rho_{21} & 1 & \rho_{23} & \rho_{24} \\
\rho_{31} & \rho_{32} & 1 & \rho_{34} \\
\rho_{41} & \rho_{42} & \rho_{43} & 1
\end{array}\right]
$$

where $\rho_{i j}$ represent the correlation between different types of market outlets

\section{Results and discussion}

Demographic and socioeconomic characteristics

The result presented in Table 1 indicated that $93.25 \%$ of the respondents were male-headed, and the rest $6.25 \%$ were female-headed. This implies that male-household heads have access of marketing information with good market networks due to the interaction ability with one or more wheat product buyers than females who are in 
Table 1 Mean and proportion of households' characteristics

\begin{tabular}{|c|c|c|c|}
\hline Continuous variables & & Mean & SD \\
\hline Age in years & & 45.91 & 10.33 \\
\hline Family size in MDE & & 5.72 & 1.82 \\
\hline Land size in ha & & 1.38 & 0.59 \\
\hline Livestock number in TLU & & 5.53 & 2.86 \\
\hline Distance to the nearest market in $\mathrm{km}$ & & 1.99 & 1.32 \\
\hline Dummy variable & Response & Frequency & Percentage \\
\hline \multirow[t]{2}{*}{ Sex } & Male & 152 & 93.25 \\
\hline & Female & 11 & 6.25 \\
\hline \multirow[t]{2}{*}{ Education status } & Illiterate & 97 & 59.51 \\
\hline & Literate & 66 & 40.49 \\
\hline \multirow[t]{2}{*}{ Non-farm income } & Yes & 59 & 36.20 \\
\hline & No & 104 & 63.80 \\
\hline \multirow[t]{2}{*}{ Credit access } & Yes & 47 & 28.83 \\
\hline & No & 116 & 71.17 \\
\hline
\end{tabular}

most cases restricted to home chores. Similarly, the mean age of household heads was 45.91 years, which implies most of the wheat producers had more experience in wheat production and channel choice. Likewise, the mean family size and land size of households were 5.72 in man day equivalent and 1.38 ha, respectively. Moreover, on average the total livestock holding in tropical livestock unit was 5.53. This implies that households that owned large livestock can generate high returns to cover high bargaining cost. In addition, the majority of respondents (59.51\%) were illiterate. Furthermore, most respondents had no off-/non-farm income source $(63.8 \%)$ and no credit source $(71.17 \%)$ (Table 1$)$.

\section{Determinants of wheat market channel choice}

In the study areas, wheat producers have different market channel choice options to sell their product. However, there are various factors that affect producers to select the appropriate wheat channels. The decision of producers to choose such market channels was determined by various demographic, socioeconomic and institutional factors. The Wald Chi-square statistic was used to test the overall significance of variables. This result implied that the model was significant at $1 \%$ level, and the explanatory power of the factors included within the model is satisfactory. The likelihood ratio test of the null hypothesis of independence of the market channel choice $\left(\rho_{21}=\right.$ $\left.\rho_{31}=\rho_{41}=\rho_{32}=\rho_{42}=\rho_{43}=0\right)$ is significant at $1 \%$. Therefore, the null hypothesis that all the $\rho$ (Rho) values are jointly equal to 0 is rejected, indicating the goodness of fit of the model and the decisions to choose such market channels was interdependent on each other. Thus, the use of a multivariate probit model is vindicated to determine factors that affect market channel's choice (Table 2).

Moreover, there are differences in market channel choice behavior among producers, which was reflected in the likelihood ratio statistics. Separately considered, the $\rho$ values $\left(\rho_{\mathrm{ij}}\right)$ indicate the degree of correlation between each pair of outlet choice. The results of model revealed that among eight variables included in the model, five variables were found to have a significant effects on the willingness to choose of wheat market outlets (Table 2).

The channel choice of assembler was affected by age, total livestock holding and credit access negatively and significantly, while land size had a positive and significant effect. The channel choice of a wholesaler was positively and significantly affected by literacy status of household heads. Likewise, the channel choice of a retailer was significantly and positively affected by literacy status and total land-holding size, while off-farm income had a significant and negative effect. Moreover, the channel choice of consumer was significantly and negatively affected by literacy status and land-holding size, whereas non-farm income affected positively (Table 2).

The marginal success probability for each market channel decision is expressed, as the likelihood of choosing a retailer is relatively low (25.5\%) compared with the probability of selecting assembler market channel (30.8\%), consumer market channel $(34.7 \%)$ and wholesaler market channel $(76.5 \%)$. This is a good evidence that farmers were not interested to sell their product to retailer market channel, even if they got good market price than other market channels due to higher marketing cost and retailer problems on scaling or weighting of their product. If wheat producers could choose all four market 
Table 2 MVP model estimation for determinants of wheat producer's outlet choice

\begin{tabular}{|c|c|c|c|c|}
\hline \multirow[t]{2}{*}{ Variables } & \multicolumn{4}{|c|}{ Coefficients (channel choice equation) } \\
\hline & Assembler (1) & Wholesaler (2) & Retailer (3) & Consumer (4) \\
\hline Age of household in years & $-0.027^{* *}$ & 0.005 & -0.002 & 0.015 \\
\hline Literacy status of household & -0.017 & $0.502^{* *}$ & $0.442^{* *}$ & $-0.460^{* *}$ \\
\hline Total land size in ha & $0.434^{*}$ & -0.347 & $0.581^{* *}$ & $-0.500^{* *}$ \\
\hline Crop productivity (yield/ha) & -0.022 & 0.030 & -0.001 & -0.030 \\
\hline Total livestock holding (in TLU) & $-0.077^{*}$ & -0.003 & 0.061 & 0.002 \\
\hline Access to credit & $-0.855^{* * *}$ & 0.007 & 0.154 & -0.040 \\
\hline Non-farm income & 0.306 & -0.082 & $-0.544^{* *}$ & $0.554^{* *}$ \\
\hline Distance to nearest market in km & -0.083 & -0.054 & -0.120 & 0.048 \\
\hline Constant & $1.354^{*}$ & $-1.680^{* *}$ & $-1.533^{* *}$ & 0.301 \\
\hline Predicted probability & 0.308 & 0.765 & 0.255 & 0.347 \\
\hline$\rho_{21}$ & & -0.147 & & \\
\hline$\rho_{31}$ & & $-0.361^{* * *}$ & & \\
\hline$\rho_{41}$ & & $-0.398^{* * *}$ & & \\
\hline$\rho_{32}$ & & -0.157 & & \\
\hline$\rho_{42}$ & & $-0.271^{* *}$ & & \\
\hline$\rho_{43}$ & & -0.030 & & \\
\hline Wald $\mathrm{Chi}^{2}(32)$ & & $79.09^{* * *}$ & & \\
\hline \multicolumn{5}{|c|}{ Likelihood ratio test of independence $\rho_{21}=\rho_{31}=\rho_{41}=\rho_{32}=\rho_{42}=\rho_{43}=0, \operatorname{Chi}^{2}(6)=32.65^{* * *}$} \\
\hline Joint probability (success) & & 0.005 & & \\
\hline Joint probability (failure) & & 0.077 & & \\
\hline
\end{tabular}

Dependent variable is outlet choice; ${ }^{* * *},{ }^{* *}$ and ${ }^{*}$ are statistically significant at $1 \%, 5 \%$ and $10 \%$ level of significance, respectively

channels, their joint likelihood of choosing all these market channels would be only $0.05 \%$. It was unlikely for producers to choose all four market channels simultaneously. This was justified as either the fact that simultaneous choosing of all market channels was unaffordable for the smallholder wheat producers, or all four market channels were not simultaneously accessible in the study areas. However, their joint probability of not choosing all four market channels was $7.7 \%$, implying that the households were more unlikely to fail. This evidence suggests that choosing the right mix of market channels was determined by different factors for each market channel (Table 2).

Age of a household head was found to have a negative relationship with rural assembler wheat market outlets and significant at $1 \%$ probability level. This implies that as the age of household increases by a year, the probability of farmers to sell their product to the assembler market outlet will decrease by 0.027 , ceteris paribus. The possible justification is the older household head appears not to trust the price given by local traders and instead prefers urban traders like wholesalers to form a long-term relationship and to get a good selling price of wheat. This result in line with [25] confirmed that older farmers are not risk takers to sell their product in the different markets like younger farmers. The result of [15] also confirmed that older farmers take their decision to choose better market outlet which gives higher price more easily than the young farmers. By contrasting, [2] revealed that older farmers prefer rural markets than urban market.

Literacy status of household heads was significantly influenced by the likelihood of choosing wholesaler, retailer and consumer at $2 \%$ significant level. As household head's become literate, the probability of choosing wholesaler and retailer market channel increased by $50.2 \%$ and $44.2 \%$, respectively. However, the probability of choosing consumer's market outlet is decreased by $46 \%$. This can be explained by the fact that as a producer becomes literate, he/she has good skill and knowledge of agricultural marketing, which enables them to sell their produce in a profitable market outlet such as wholesaler and retailer market than a consumer market. This study is consistent with $[14,15,17]$, and they found that education status of respondents affects mango, dairy and onion market channel choice negatively (Table 2).

The likelihood of household heads to choose an assembler market outlet was negatively influenced by access to credit service at $1 \%$ levels of significance. The finding revealed that as the farmers have not accessed credit service, the probability of participating in a wholesaler 
market channel will be decreased by $85.5 \%$. The possible explanation is that obtaining appropriate wheat market outlet, particularly urban wholesaler, is both capital and labor-intensive tasks. Livestock holding also affects the likelihood of choosing assembler market outlet negatively and significantly at $10 \%$ significant level. This implies that for a unit increase in livestock holding in TLU, the likelihood of choosing assembler market outlet decreases by 7.7\%. This implies that farmers who have more livestock can generate high cash income by selling their livestock, so they can search a best market outlet, and even they travel to urban centers to sell their product to the most profitable market channels than local traders. This study in line with [4] confirmed that livestock hold had positively and significantly affected the access of milk market outlet.

The likelihood of choosing a retailer market channel was negatively affected by participation of household in non-farm activities at 5\% levels of significance. On the other hand, consumer market channel was positively and significantly affected by participation in non-farm activities at $5 \%$ level of significance. This implies that as the farmer involved in non-farm activities, the probability of participating in retailer and consumer market outlet will decrease and increase by $54.4 \%$ and $55.4 \%$, respectively. The possible justification is most producers have an intimate relationship with consumers, and the most sources of non-farm income for wheat producers were consumers. This makes the producers choose consumers market outlet as compared to retailer's market outlet. This result consistent with [21] revealed that participation in non-/ off-farm activities has a negative effect on retailer market channel choice.

Farm size of producers had a positive and significance effect on the choice of assembler and retailer outlets at $1 \%$ and $5 \%$ significance level, respectively. It also negatively and significantly associated with consumer market channel choice at 5\% significant level. This implies that as the total land-holding capacity of farmers increased in a hectare, the probability to choose assembler and retailer market channel also increased by $43.4 \%$ and $58.8 \%$, respectively. However, the probability to choose consumer market outlet was decreased by $50 \%$. The possible reason is, as smallholder farmers own large farming size, they can produce a large amount of wheat and sell to assembler and retailer in bulk to reduce marketing cost than consumer's market outlet. This is because consumers did not purchase large amounts of wheat product from farmers, and as a result they try to sell the produce to assemblers and retailer's market outlet (Table 2).

\section{Conclusion and Recommendation}

The study was conducted in northwestern Ethiopia with the objective of identifying factors that affect market outlet choice decision of wheat producers. In order to undertake this research, combinations of quantitative and qualitative date were collected from 163 wheat producers and analyzed using the descriptive and multivariate probit models. Since wheat is the major crop which grows for consumption and market purpose in North Gondar Zone, farmers can select one or more appropriate channels based on its comparative advantage and accessibility of channels for farm product to maximize their return. The simulated maximum likelihood (SML) estimation result shows the probabilities for wheat producers to choose wholesaler, consumer, assembler and retailer market outlets were 76.5, 34.7, 30.8 and $25.5 \%$, respectively. Similarly, the result of a multivariate probit model indicated that the probability to choose the assembler market outlet was significantly influenced by age of household, farming size, livestock holding and accessibility of credit service as compared to accessing wholesalers' wheat market outlet. Likewise, the probability of accessing retailers' and consumer's wheat market outlets was significantly influenced by literacy status of households, farming size and non-farm income source. Hence, to promote the flow of wheat product from producers to the ultimate consumers through different outlets, the producer's knowledge and skill on marketing and production should be improved through training, mass media and redesign, strengthening and developing implementation strategies on extension education. Moreover, the development agents should provide appropriate extension service on how to manage their farming land to produce quality and quantity of product of wheat demanded by every market agent, which makes them profitable by accessing appropriate market outlets. Furthermore, smallholder farmers are not a homogenous group; they differ in their resources owned and capabilities to invest in agricultural upgrading due to shortages of working capital and lack of liquidity for longer term upgrading investments. Hence, it is important to provide credit service to producers at the fair interest rate because it helps them to participate in both wheat production and marketing activities and facilitate the time to search the appropriate market channel.

\section{Abbreviations}

CSA: Central Statistical Agency; e: error; GDP: gross domestic product; MVP: multivariate probit model; MDE: man day equivalent; MVN: multivariate normal distribution; $\mathrm{n}$ : sample size; N: target population; SML: simulated maximum likelihood; TLU: tropical livestock unit. 


\section{Authors' contributions}

All authors read and approved the final manuscript.

\section{Acknowledgements}

The authors would like to thank the University of Gondar, as financial support for this research was obtained from the University of Gondar. Moreover, we thank my colleagues Mr. Agumase Kindie, the data respondents, enumerators and district experts for their valuable response during data-collection process.

\section{Competing interests}

The authors declare that they have no competing interests.

\section{Availability of data and materials}

The authors want to declare that they can submit the data at any time based on publisher's request. The datasets used and/or analyzed during the current study will be available from the authors on reasonable request.

\section{Consent for publication}

Not applicable.

\section{Ethical approval and consent to participate}

Ethical clearance letters were collected from University of Gondar research and community service directorate and North Gondar Zone administrative office to care for both the study participants and the researchers. During survey, official letters were written for each district and kebele/villages/informed verbal consent was obtained from each client, and confidentiality was maintained by giving codes for each respondent rather than recording their name. Study participants were informed that clients have full rights to discontinue or refuse to participate in the study. Hence, all participants throughout the research, including survey households, enumerators, the supervisors and key informants, were fully informed of the objectives of the study. They were approached friendly in free moods until the end of this research.

\section{Funding}

The University of Gondar provided financial support to complete this research successfully.

\section{Publisher's Note}

Springer Nature remains neutral with regard to jurisdictional claims in published maps and institutional affiliations.

Received: 23 July 2018 Accepted: 6 December 2018

Published online: 17 December 2018

\section{References}

1. Agricultural Office of North Gondar Zone. Socio-economic profile description of North Gondar zone. Unpublished annual report, Gondar, Ethiopia; 2016.

2. Arinloye DD, Pascucci S, Linnemann AR, Coulibaly ON, Hagelaar G, Omta OS. Marketing channel selection by smallholder farmers. J Food Prod Mark. 2015;21(4):337-57.

3. Barrett CB. Smallholder market participation: concepts and evidence from eastern and southern Africa. Food Policy. 2008;33(4):299-317.

4. Berhanu K, Derek B, Kindie G, Belay K. Factors affecting milk market outlet choices in Wolaita zone, Ethiopia. Afr J Agric Mark. 2013;1 (2):024-31.

5. Best R, Ferris S, Schiavone A. Building linkages and enhancing trust between small-scale rural producers, buyers in growing markets and suppliers of critical inputs. In: Beyond agriculture-making markets work for the poor. Proceedings of an international seminar 2005. vol. 28, p. 19-50.
6. Bizualem GA, Degye HG, Zekarias SN. Analysis of marketed surplus of coffee by smallholder farmers in Jimma zone, Ethiopia. J Biol Agric Healthc. 2015:5(5):242-52.

7. CSA (Central Statistical Agency). Area and Production of Crops. Country Level, Part II, Addis Ababa; 2007.

8. CSA (Central Statistical Agency). Report on Area and Production of Major crops. Ethiopian Agricultural Sample Survey Private Peasant Holdings, Meher Season -Volume I. Statistical Bulletin. Addis Ababa; 2010.

9. CSA (Central Statistical Authority). Agricultural sample survey report on area and production of crops (private peasant holdings, meher season). Volume I. CSA, Addis Ababa, Ethiopia; 2013.

10. Degye G, Belay K, Mengistu K. Is food security enhanced by agricultural technologies in rural Ethiopia? Afr J Agric Resour Econ. 2013;8(1):58-68.

11. Demeke M, Di Marcantonio F. Analysis of incentives and disincentives for wheat in Ethiopia. Technical notes series, MAFAP, FAO, Rome; 2013.

12. FAOSTAT. "Crops". Countries - Select All; Regions - Africa + (Total); Elements - Area and Production Quantity; Items - Wheat; Years - 2010-2016. http://www.fao.org/faostat/en/\#data/QC/. Accessed 18 Aug 2018.

13. Lundy M, Gottret M, Cifuentes W, Ostertag C, Best R, Peters D, Ferris S. Increasing the competitiveness of market chains with smallholder producers. Field Manual 3. The Territorial Approach to Rural Agro-enterprise Development. Centro Internacionale de Agricultura Tropical, Cali, Colombia; 2004.

14. Maina CM, Lagat JK, Mutai BK. Effect of transaction costs on choice of mango marketing channel: the case of small scale farmers in Makueni County, Kenya. J Agric Vet Sci. 2015;8(4):54-62.

15. Melese T, Goshu D, Tilahun A. Determinants of outlet choices by smallholder onion farmers in Fogera district Amhara Region, Northwestern Ethiopia. J Hortic For. 2018;10(3):27-35.

16. Moti J, Berhanu G. Interdependence of smallholders' net market positions in mixed crop-livestock systems of Ethiopian highlands. J Dev Agric Econ. 2012;4(7):199-209.

17. Mutura JK, Newton N, Maina M, Stephen KW. Vertical and horizontal integration as determinants of market channel choice among smallholder dairy farmers in lower Central Kenya. Asian J Econ Empir Res. 2015;2(2):83-90.

18. Shewaye A. Econometric analysis of factors affecting haricot bean market outlet choices in Misrak Badawacho District, Ethiopia. Int J Res Stud Agric Sci. 2016;2(9):6-12.

19. Sultan U, Jema H, Eluid B. Factors affecting market outlet choice for wheat in Sinana District, Bale zone, Ethiopia. J Econ Sustain Dev. 2017;8(17):20-7.

20. Tarekegn K, Haji J, Tegegne B. Determinants of honey producer market outlet choice in Chena District, southern Ethiopia: a multivariate probit regression analysis. J Agric Food Econ. 2017;5(20):2-14

21. Tefera T. Analysis of chickpea value chain and determinants of market options choice in selected districts of southern Ethiopia. J Agric Sci. 2014;6(10):26

22. World Bank. World development indicators. Green Press initiative. Washington: World Bank; 2007.

23. Yamane T. Elementary sampling theory. Englewood Cliffs: Printice Hall Inc; 1967.

24. Yu L, Hurley T, Kliebenstein J., Orazen P. Testing for complementarities and substitutability among multiple technologies: the case of US Hog Farms. Working paper, No. 08026. Ames, IA, USA: lowa State University, Department of Economics; 2008.

25. Zegeye T, Tadesse B, Tesfaye S. Determinants of adoption of improved maize technologies in major maize growing regions in Ethiopia. Proceedings of the Second National Maize Workshop of Ethiopia, Addis Ababa, Ethiopia; 2001. 